\title{
THE EFFECT OF E-COMMERCE WEB SITE SECURITY ON PURCHASE INTENTION
}

\author{
Adnan Veysel ERTEMEL ${ }^{1}$, Mustafa Emre CIVELEK ${ }^{2}$
}

\begin{abstract}
This study investigates the effect of website security, as a key dimension of e-service quality, on purchase intention, perceived value and brand loyalty in business-to-consumer (B2C) e-commerce context. Hypotheses were developed based on previous literature. Afterwards, an empirical research was conducted with the data collected from 464 e-commerce customer to verify the hypotheses. Structured equation modeling was used to test the hypotheses. Having analyzed the results, it is found out that website security in e-commerce affects customer purchase intention directly. Furthermore, website security indirectly affects purchase intention through brand loyalty and perceived value. The study has important managerial implications stressing the importance of customer perception regarding security level of $\mathrm{B} 2 \mathrm{C}$ e-commerce web sites.
\end{abstract}

Keywords: E-Commerce, Web Site Security, Purchase Intention, Perceived Value, Brand Loyalty

JEL Codes: M31, L81, M15

\section{E-TICARET WEB SITTELERINDE WEB SITESI GÜVENLIĞİNIN SATINALMA NIYYTII ÜZERINDEKI ETKISİ}

\section{Özet}

$\mathrm{Bu}$ çalışmada $\mathrm{B} 2 \mathrm{C}$ e-ticaret web sitelerinde, e-hizmet kalitesi boyutlarından web sitesi güvenliğinin satınalma niyeti, algılanan değer ve marka sadakati üzerine etkisi incelenmiştir. Konuyla ilgili literatür ortaya konduktan sonar hipotez geliştirmesi yapılmıştır. Ardından 464 e-ticaret müşterisi üzerinde amprik bir araştırma gerçekleştirilmiştir. Yapısal eşitlik modeliyle hipotezler sınanmışıır. Çalışma sonunda B2C e-ticaret markalarında websitesi güvenliğinin satınalma niyetini doğrudan etkilediği bulunmuştur. Ayrıca, websitesi güvenliğinin satınalma niyetini dolaylı yoldan, algılanan değer ve marka sadakati üzerinden de etkilediği saptanmıștır. Bu çalışma müşterilerin web sitesinin güvenliği ile ilgili algılarının önemi vurgulayan yönetimsel sonuçlar ortaya çıkarmışıtır.

Anahtar Kelimeler: E-Ticaret, Web Sitesi Güvenliği, Satınalma Niyeti, Algılanan Değer, Marka Sadakati

Jel Kodları: M31, L81, M15

\section{Introduction}

Today, Usage of e-commerce is increasing at a global scale. Starting from developed countries, adoption rate of e-commerce medium is such that it's expected to be the default way of conducting business in the upcoming years. E-commerce can be defined as conducting business transactions of all kinds by exploiting the Internet. Proactive businesses view e-commerce as a strategic weapon which extends their consumer reach tremendously by removing borders worldwide, enable 7/24 trading capability, enrich interactions between multiple parties (both B2B and $\mathrm{B} 2 \mathrm{C})$, bypass unnecessary intermediaries thereby reducing transaction costs. Furthermore, online medium enable businesses to integrate online communications into their businesses processes leading to entirely business processes exploiting the interactivity and automation of the Internet.

\footnotetext{
${ }^{1}$ Dr. Öğr. Üyesi, İstanbul Ticaret Üniversitesi, avertemel@ticaret.edu.tr

${ }^{2}$ Dr. Öğr. Üyesi, İstanbul Ticaret Üniversitesi, ecivelek@ticaret.edu.tr
} 
Researches have been studying e-commerce in various aspects. However, only a few studies have attempted to address e-service quality dimensions and their effect on customer perceived value and brand loyalty (Yang et. al 2005, Jiang et. al 2015).

Based on mainly adopted quality dimensions in service sectors (Parasuraman 1985; Parasuraman 1988a; Parasuraman 1988b), various scholars developed different dimensions of e-service quality. Most widely accepted e-service quality scales include have specific items in common (i.e. website security, efficiency, accessibility, ease of use, visual appeal, customer service, reliability) (Zeithaml et al., 2000; Jiang et al., 2016; Johnston et al., 1990; Wolfinbarger et al, 2002; Ranganathan, 2002). Among those common dimensions, this study specifically focuses on website security of B2C e-commerce websites and analyzes its effect on perceived value and brand loyalty. Furthermore, this study attempts to link these variables to the actual customer behavior, namely, purchase intention. More specifically, this study analyzes the effect of website security found in B2C e-commerce websites on purchase intention directly, and indirectly through brand loyalty and perceived value. In conceptual background, e-service quality, website security, customer perceived value, brand loyalty and purchase intention concepts are discussed. Afterwards, research model and methodology are introduced. Finally, results of the research are analyzed and discussed. With regard to previous studies, the most outstanding difference of this study is that the constructs included in the conceptual model of this research have not been analyzed before in such a hybrid structure. The performance of a B2C enterprise is imperatively depended on actual behavior which is represented by purchase intention. With its hybrid structure, this model, therefore, is important and unique due to its potential to better explain purchase intention.

\section{Conceptual Background}

\subsection{Defining Service Quality in E-Commerce}

According to Kuo (2003), e-commerce service quality is defined as customers' overall assessment of the quality of web sites. Santos (2003) define it as the evaluations of the experience of the e-service in terms of quality and excellence of the e-service delivery in online medium. Service quality concept has its roots on Parasuraman's well known SERVQUAL scale (Parasuraman, 1985; 1988). Many other scholars developed similar scales that attempt to measure service quality in e-commerce context. Among those studies, many of them, including the scales developed by Johnston et al. (1990), Wolfinbarger et al (2002), Liu et al. (2000), Yoo et al. (2001), Law et al., (2000) and Ranganathan, (2002) have website security as one of the crucial dimensions in service quality. Similarly, Zeithaml et al. (2000) mention security as one of the key constructs in e-service quality.

\subsubsection{Website security}

Website security is a major obstacle in online transactions. Udo (2001) pinpoints security concern as one of the main reasons why web visitors prefer not to make online purchases. Therefore, e-commerce brands have to assure their customers that they can safely share their sensitive information like credit card details without worrying about third parties' interference.

Zeithaml et al. (2000) define website security as the degree to which the customer believes the site is safe from intrusion and personal information is protected. Likewise, Dong et al. (2004) mention that security vulnerabilities may lead to major risks and bring in difficulties in growth of e-commerce website. According to Turban et al. (2006), website security phenomenon encompasses confidentiality, integrity, authentication, and nonrepudiation (assurance that someone cannot deny authenticity of their signature) in online transactions. 
In order to remedy lack of trust in online medium, e-commerce brands apply authenticated security policies like encryption or digital certificates. (Glass, 1998).

Wolfinbarger et al. (2003) state that website security represents a B2C e-commerce web sites' security of payment (i.e. credit cards) and how they manage privacy of shared information about the customers. Krishnamurthy (2001) pointed out that e-commerce websites should also be certified by 3rd party assurance to improve their security perception.

\subsection{Perceived Value}

Perceived value concept refers to customers' assessment of fairness with regard to what they get and what they pay (monetary cost effort given etc.) (Bolton et al., 1999; Oliver et al., 1988). Perceived value is closely related with equity theory (Oliver et al., 1988). Equity theory, focuses on customers' overall assessment of the risks and rewards when interacting with a brand or its product. E-commerce is a typical area where equity theory is especially relevant and important. For e-commerce brands to maintain long term relationships with their customers, they have to convince them that they are treated equitably. That is, customers should feel convinced that they receive what they deserved in the ongoing exchanges with the brand (Oliver et al., 1988). Yang et al. (2004) also stress the critical importance of increasing perceived value for increasing customer loyalty.

\subsection{Brand Loyalty}

Brand loyalty concept implies customers' commitment level in their relationship with the brands. This commitment could be demonstrated by repeated purchases, biases in favor of the brand or just inner attitudes about the brand (Odin et. all, 2001). Brand loyalty could also take effect with someone's tendency to recommend the brand to his acquaintances (Boulding et al. 1993). As a consequence, brand loyalty deserves special attention in ecommerce brands' brand-building efforts.

\subsection{Purchase Intention}

E-commerce brands should ultimately link their efforts to purchase behavior in order to attain business profitability and hence become sustainable. Theory of planned behavior argues that behavioral intention is the key to predicting customer purchase behavior (Ajzen 1991). Lin (2006) also states that purchase intention could be used to represent actual purchase behavior. Therefore, in this study, purchase intention is used to predict actual behavior.

\section{Research Model and Hypotheses Development}

\subsection{The Relationship between Website Security and Perceived Value}

Zeithaml et al. (2000) point out that, among other e-service quality dimensions like reliability, ease of use, efficiency and customization, website security/privacy is a key dimension of e-service quality that affects perceived value, which in turn influences purchase intention. According to the results of these studies it can be suggested that website security exert positive effect on perceived value in B2C e-commerce. Thus, in the light of the existing literature, following hypothesis was developed:

H1: Web Site Security has a positive effect on Perceived Value.

\subsection{The Relationship between Perceived Value and Brand Loyalty}

Previous literature has shown perceived value as a major precedent to customer loyalty (Agustin et al., 2005). Parasuraman et al. (2000) and Chen et al. 
(2003) have documented increased perceived value as a predictor of customer patronage. Oliver et al. (1988) argue that high perceived value leads to increased brand loyalty and less inclination to switch to another brand.

Thus, in the light of the existing literature, following hypothesis was developed:

H2: Perceived Value has a positive effect on Brand Loyalty.

\subsection{The Relationship between Brand Loyalty and Purchase Intention}

Wang et al. (2006) and Kamariah et al. (2005) have shown that increased brand loyalty increases the likelihood of purchase intention. Therefore, in e-commerce context, we can conclude that highly loyal customers also have a steady purchase intention to buy products from the brand.

Thus, in the light of the existing literature, following hypothesis was developed:

H3: Brand Loyalty has a positive effect on Purchase Intention.

\subsection{The Relationship between Web Site Security and Purchase Intention}

Zeithaml et al. (2000) and Schlosser et al. (2006) argue that, among other factors, website security is a crucial factor that influences online purchase intention. Further, Palmer et al. (2000) indicate that an e-commerce website impression that conveys a good website security leads to confidence in that e-commerce brand. Conversely, Hui et al. (2007) mention that perception of risk related to security issues like loss of consumers' shared information is a big barrier to adoption of e-commerce, highlighting the importance of website security. In different studies, Ranganathan et al. (2002), Yousafzai et al. (2003) and Kim et al. (2008) point out the positive influence of website security in e-commerce on purchase intention.

Thus, in the light of the existing literature, following hypothesis was developed:

H4: Website Security has a positive effect on Purchase Intention.

The conceptual model of the research is shown in Figure 1. In the conceptual model there are four hypotheses. These hypotheses try to explain effect of web site security on the purchase intention.

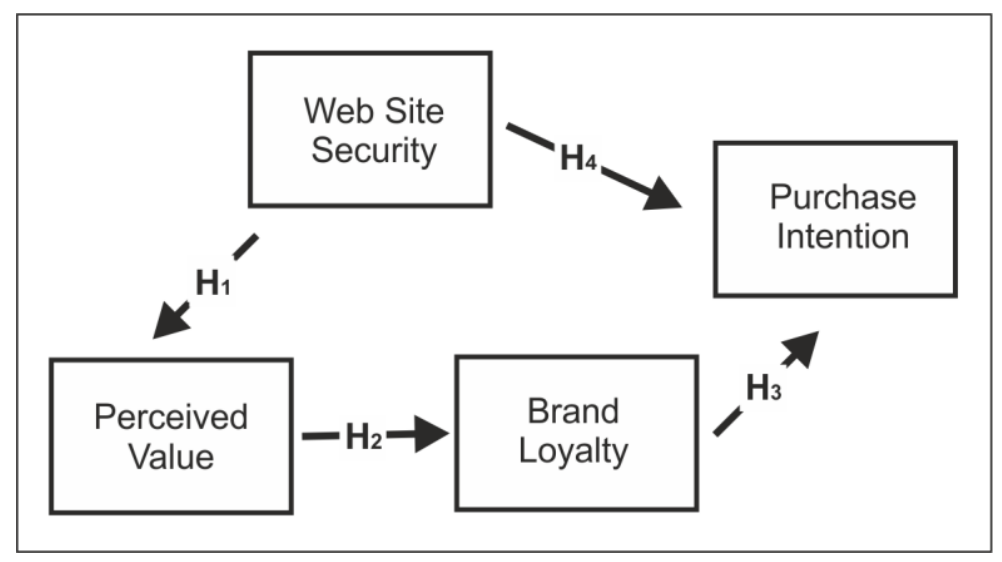

Figure 1. Conceptual Research Model

\section{Research Methodology}

Quantitative data collected by means of a questionnaire which used five-point ordinal Likert scale ranging from strongly disagree to strongly agree. The measures used in the survey adopted from the literature. Firstly, the reliability and validity of the measures were determined. Subsequently, structural equation modeling method was used to test the hypotheses of conceptual research model. 
Structural equation modeling is a multi-variable statistical method. This method was chosen to explain direct and indirect relationships among the constructs in a single model (Civelek, 2018). This method is taking measurement errors into consideration (Byrne, 2010). Therefore it is superior to multiple regression analysis. SPSS and AMOS statistics programs were used for analyses.

\subsection{Measures and Sampling}

Scale adopted from Jiang et al. (2016) was used to measure website security (3 items), brand loyalty (6 items) and perceived value (5 items) (Jiang, Jun, Yang, 2016). And scale adopted from Chen et al. (2003) was used to measure purchase intention (3 items) (Chen, Teng, 2013). More than 500 distributed, 464 valid questionnaires were gathered from eight prominent cities throughout Turkey in 2018. 240 of the respondents are male and 224 are female. Population of this research consists of Turkish e-Commerce web site users.

\subsection{Construct Validity and Reliability}

The confirmatory factor analysis (CFA) was performed for 16 items remaining after the exploratory factor analysis (EFA). EFA was performed for data purification. CFA was conducted to determine convergent validity of the constructs (Anderson \& Gerbing, 1988). CFA model fit indices have adequate fit: $\chi 2 / \mathrm{DF}=2.015$, CFI $=0.943$, IFI $=0.943, \mathrm{RMSEA}=0.066 . \chi^{2}$ is The Likelihood Ratio Chi-Square Test. The analysis shows the conformity of the initial model and the acquired model. A $\chi 2 / D F$ ratio is under the threshold level of 3 (Bagozzi \& Yi, 1990) and shows good fit. Furthermore, other fit indices $(\chi 2 / \mathrm{DF}=2.015, \mathrm{CFI}=0.943, \mathrm{IFI}=0.943, \mathrm{RMSEA}=0.066$. $)$ exceeded their recommended thresholds and show good fit.

Table 1. Confirmatory Factor Analysis Results

\begin{tabular}{|c|c|c|c|c|}
\hline Variables & Items & & $\begin{array}{l}\text { Standard. } \\
\text { Factor } \\
\text { Loads } \\
\end{array}$ & $\begin{array}{l}\text { Unstand. } \\
\text { Factor } \\
\text { Loads }\end{array}$ \\
\hline \multirow{3}{*}{$\begin{array}{l}\text { Web Site } \\
\text { Security }\end{array}$} & Wsc0226 & I feel the risk associated with online transactions is low & 0.765 & 1 \\
\hline & Wsc0125 & I feel secure in providing sensitive information for online transactions. & 0.742 & 0.855 \\
\hline & Wsc0327 & I feel safe in my online transactions. & 0.811 & 0.973 \\
\hline \multirow{5}{*}{$\begin{array}{l}\text { Perceived } \\
\text { Value }\end{array}$} & Pva0434 & $\begin{array}{l}\text { Comparing what I pay to what I get, I think the company provided me } \\
\text { with good value. }\end{array}$ & 0.681 & 1 \\
\hline & Pva0535 & $\begin{array}{l}\text { Comparing what I pay to what I might get from other competitive } \\
\text { companies, I think the company provides me with good value. }\end{array}$ & 0.717 & 1.040 \\
\hline & Pva0333 & $\begin{array}{l}\text { Compared to alternative companies, the company provides more free } \\
\text { services }\end{array}$ & 0.534 & 0.900 \\
\hline & Pva0131 & $\begin{array}{l}\text { Compared to alternative companies, the company offers attractive } \\
\text { product costs. }\end{array}$ & 0.530 & 0.801 \\
\hline & Pva0232 & $\begin{array}{l}\text { Compared to alternative companies, the company charges me fairly for } \\
\text { similar products/services }\end{array}$ & 0.677 & 1.048 \\
\hline \multirow{5}{*}{$\begin{array}{l}\text { Brand } \\
\text { Loyalty }\end{array}$} & Bly0641 & I intend to do more business with the present company. & 0.579 & 1 \\
\hline & Bly0136 & I say positive things about the company to other people. & 0.827 & 1.537 \\
\hline & Bly0439 & $\begin{array}{l}\text { I would post positive messages about the company on some Internet } \\
\text { message board. }\end{array}$ & 0.632 & 0.227 \\
\hline & Bly0237 & $\begin{array}{l}\text { I would recommend the company to those who seek my advice about such } \\
\text { matters. }\end{array}$ & 0.867 & 0.517 \\
\hline & Bly0338 & I would encourage friends and relatives to use the company. & 0.722 & 1.426 \\
\hline \multirow{3}{*}{$\begin{array}{l}\text { Purchase } \\
\text { Intention }\end{array}$} & Pin0142 & I am positive towards buying the products on the website & 0.733 & 1 \\
\hline & Pin0344 & I think it is a good idea to buy products at the website & 0.841 & 1.107 \\
\hline & Pin0243 & The thought of buying products from the website is appealing to me & 0.843 & 1.101 \\
\hline
\end{tabular}

$\mathrm{p}<0.05$ for all items 
CFA results are shown in Table 1. The standardized factor loads of each item are larger than 0.5 and significant. These results determine the convergent validity of the scales. In order to determine the discriminant validity, the square roots of average variance extracted (AVE) values were calculated and compared with correlation values of the constructs in the same column. In Table 2, the diagonals indicate the square root of AVE value of each variable. And as shown in Table 2, the square roots of AVE values are beyond the correlation values in each column (Byrne, 2010). Reliability of each construct was also calculated. Composite reliability and Cronbach $\alpha$ values were calculated separately. These values are beyond the threshold level (i.e. 0.7) (Fornell \& Larcker, 1981). Pearson correlation coefficients, composite reliabilities, average variance extracted values, Cronbach $\alpha$ values, means and standard deviations of the constructs are shown in Table 2.

Table 2. Construct Descriptives, Correlation and Reliability

\begin{tabular}{lllll}
\hline Variables & 1 & 2 & 3 & 4 \\
\hline 1.Web Site Security & $(0.773)$ & & & \\
2.Perceived Value & $0.449^{*}$ & $(0.632)$ & & \\
3.Brand Loyalty & $0.274^{*}$ & $0.521^{*}$ & $(0.733)$ & \\
4.Purchase Intention & $0.381^{*}$ & $0.414^{*}$ & $0.590^{*}$ & $(0.807)$ \\
\hline Composite reliability & 0.817 & 0.767 & 0.851 & 0.848 \\
\hline Average variance ext. & 0.598 & 0.400 & 0.538 & 0.652 \\
\hline Cronbach $\alpha$ & 0.813 & 0.785 & 0.846 & 0.844 \\
\hline Mean & 3.50 & 3.74 & 3.82 & 3.98 \\
\hline Standard Deviation & 0.83 & 0.65 & 0.74 & 0.75 \\
\hline p $<0.01$ & & & &
\end{tabular}

Note: Diagonals show the square root of AVEs.

\subsection{Test of Hypotheses}

Covariance based structural equation modelling (CB-SEM) was used to analyze the structural model. Maximum likelihood was preferred as estimation method to estimate the coefficients. The absolute and relative goodness-offit indices of the model were calculated. The absolute goodness of fit indices are the root mean square error of approximation (RMSEA) and the $\chi^{2}$ goodness of fit statistic. The relative goodness of fit indices are the comparative fit index (CFI) and the incremental fit index (IFI).

Table 3. Hypotheses Test Results

\begin{tabular}{lcc}
\hline Relationships & $\begin{array}{c}\text { Standardized } \\
\text { Coefficients }\end{array}$ & $\begin{array}{c}\text { Unstandardized } \\
\text { Coefficients }\end{array}$ \\
\hline Web Site Security $\rightarrow$ Perceived Value & $0.531^{*}$ & $0.450^{*}$ \\
Perceived Value $\rightarrow$ Brand Loyalty & $0.689^{*}$ & $0.602^{*}$ \\
Brand Loyalty $\rightarrow$ Purchase Intention & $0.560^{*}$ & $0.715^{*}$ \\
Web Site Security $\rightarrow$ Purchase Intention & $0.257^{*}$ & $0.243^{*}$ \\
\hline
\end{tabular}
$* \mathrm{p}<0.05$

As shown in Figure 2, structural model fit indices resulted as adequate fit. $\chi 2 / \mathrm{DF}$ value is 1.987 and within threshold levels (i.e. between 0 and 2). CFI and IFI are 0.943 and 0.944 respectively. RMSEA is 0.065 . The results indicated that the model has adequate fit (Civelek, 2018). As shown in Table $3, \mathrm{H}_{1}, \mathrm{H}_{2}, \mathrm{H}_{3}$ and $\mathrm{H}_{4}$ are supported. These results of the tests indicate a positive and significant relationship between web site security and perceived value, between perceived value and brand loyalty and between brand loyalty and purchase intention and between web site security and purchase intention. 


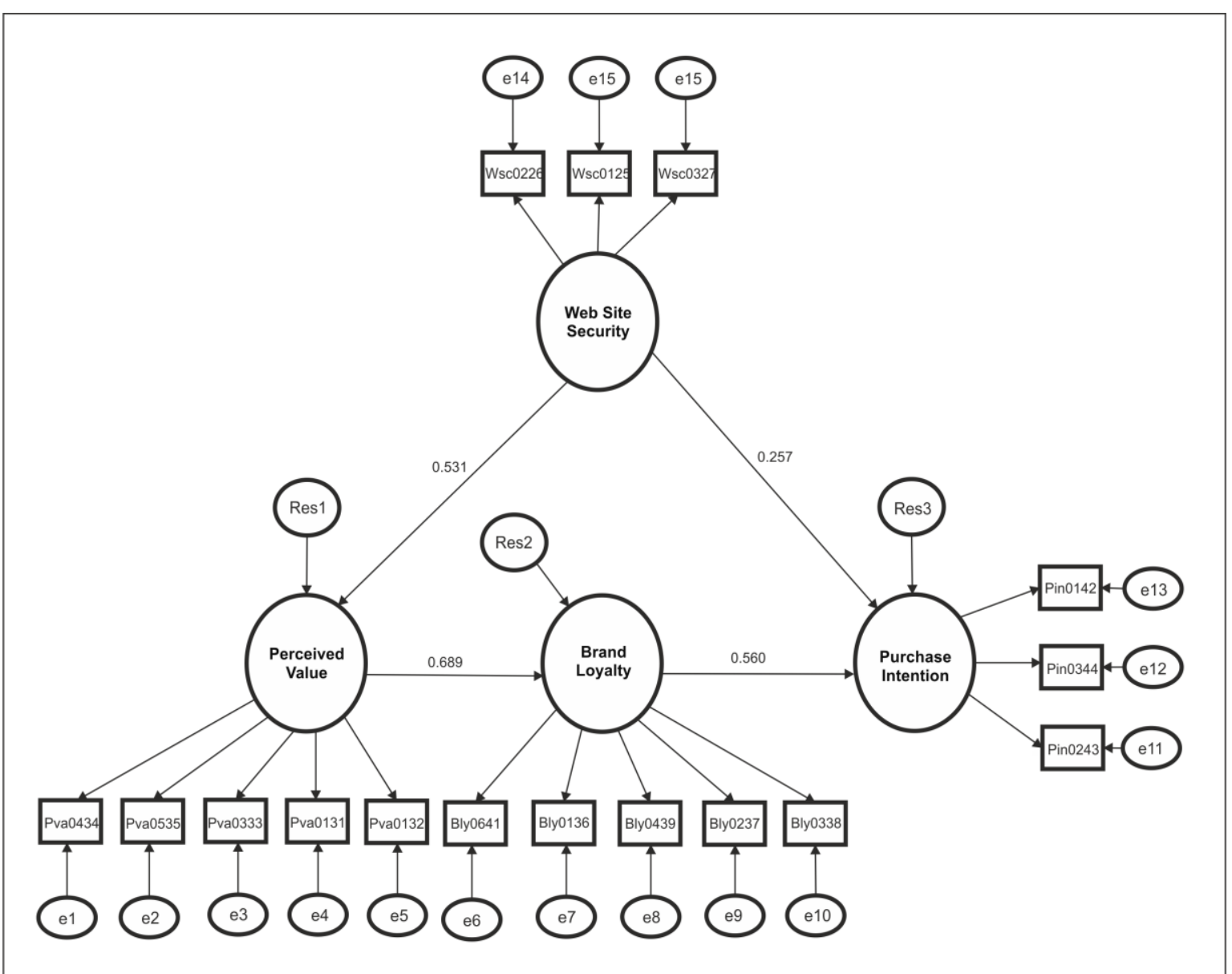

Note: $\chi 2 / \mathrm{DF}=1.987, \mathrm{CFI}=0.943, \mathrm{IFI}=0.944, \mathrm{RMSEA}=0.065$

Figure 2. Results of SEM Analysis

\section{Conclusion}

E-commerce is perceived to be a less trusted medium due to its nature. Therefore, security issues are more crucial and critical for e-commerce brands' brand-building activities. Sense of security is being prevalent eventually among the online shop customers. This research contributes to the existing e-commerce literature by investigating the relationship of website security, as an important dimension of e-service quality, with perceived value, brand loyalty and actual purchase behavior.

Several hypotheses were developed and suggested to investigate the direct and indirect relationships among the stated concepts. Having conducted the questionnaire with 464 participants, structured equation modeling technique was used to test the hypotheses. The analysis results showed that website security has direct effect on purchase intention. Additionally it indirectly affect purchase intention through perceived value and brand loyalty. One of the significant findings of this research is the effect of website security on perceived value. This construct is one of the antedescents of purchase intention.

In light of these findings, we can state that e-commerce brands should consider website security as a crucial factor both for stimulating more purchases and building their brands in the form of higher perceived value and increased brand loyalty. Hence, e-commerce brands should invest in whatever is necessary to reduce perceived risks. 
As an example, e-commerce websites might assure consumers that their personal information and credit information will be kept secure by providing a privacy policy on the web or presenting a third party security seal. Due to its hybrid structure, this model can guide B2C web site managers to develop holistic strategies to sustain in the long-run. The most prominent limitation of this research is small sample size comparing to size of the population. Therefore, future studies can be recommended to be conducted in bigger samples.

\section{References}

Agustin, C. and Singh, J. (2005), Curvilinear effects of consumer loyalty determinants in relational exchange, Journal of Market Research XLII (February), pp. 96-108.

Ajzen, I. (1991). The theory of planned behavior. Organizational behavior and human decision processes, 50(2), $179-211$.

Anderson, J. and Gerbing, D. (1988). Structural Equation Modelling in Practice: A Review and Recommended Two Step Approach. Psychological Bulletin.

Bagozzi, R. P. and Yi, Y. (1990). Assessing Method Variance in Multitrait-Multimethod Matrices: The Case of Self reported Affect and Perceptions at Work. Journal of Applied Psychology, 75(1), 547-560.

Boulding, W., Kalra, A., Staelin, R. and Zeithaml, V. A. (1993). A dynamic process model of service quality: From expectations to behavioral intentions. Journal of marketing research, 30(1), 7.

Byrne, B. M. (2010). Structural Equation Modeling with AMOS. New York: Routledge Taylor \& Francis Group.

Chen, Z. and Dubinsky, A. J. (2003). A conceptual model of perceived customer value in e-commerce: A preliminary investigation. Psychology \& Marketing, 20(4), 323-347.

Chen, M. Y. and Teng, C. I. (2013). A comprehensive model of the effects of online store image on purchase intention in an e-commerce environment. Electronic Commerce Research, 13(1), 1-23.

Civelek, M. (2018). Essentials of Structural Equation Modeling. Lincoln: University of Nebraska Lincoln-Zea Books.

Civelek, M. (2018). Yapısal Eşitlik Modellemesi Metodolojisi. İstanbul: Beta.

Fornell, C. and Larcker, D. (1981). Evaluating Structural Equation Models with Unobservable Variables and Measurement Error. Journal of Marketing Research, 18(1), 39-50.

Glass, A. D. (1998). A countdown to the age of secure electronic commerce. Credit World, 86, 29-31.

Hui, K. L., Teo, H. H. and Lee, S. Y. T. (2007). The value of privacy assurance: an exploratory field experiment. Mis Quarterly, 19-33.

Jiang, L., Jun, M. and Yang, Z. (2016). Customer-perceived value and loyalty: how do key service quality dimensions matter in the context of B2C e-commerce?. Service Business, 10(2), 301-317.

Johnston, R. and Silvestro, R. (1990). The determinants of service quality a customer based approach, Proceedings of the Decision Science Institute Conference, November, San Diego, CA.

Kamariah, N.., \& Salwani, S. (2005). Determinants of online shopping intention, 167-172.

Keller, K. L. (2001). Building customer-based brand equity: A blueprint for creating strong brands.

Krishnamurthy, S. (2001). An empirical study of the causal antecedents of customer confidence in e-tailers. First Monday, 6(1).

Law, R. and Leung, R. (2000). A study of airlines' online reservation services on the Internet. Journal of Travel Research, 39(2), 202-211.

Lin, L. Y. and Chen, C. S. (2006). The influence of the country-of-origin image, product knowledge and product involvement on consumer purchase decisions: an empirical study of insurance and catering services in Taiwan. Journal of Consumer Marketing, 23(5), 248-265.

Liu, C. and Arnett, K. P. (2000). Exploring the factors associated with Web site success in the context of Electronic commerce. Information \& Management, 38(1), 23-33. 
Oliver, R. L. and DeSarbo, W. S. (1988). Response determinants in satisfaction judgments. Journal of Consumer Research, 14(4), 495-507.

Odin, Y., Odin, N. and Valette-Florence, P. (2001). Conceptual and operational aspects of brand loyalty: An empirical investigation. Journal of Business Research, 53(2), 75-84

Palmer, J. W., Bailey, J. P. and Faraj, S. (2000). The role of intermediaries in the development of trust on the WWW: The use and prominence of trusted third parties and privacy statements. Journal of ComputerMediated Communication, 5(3), JCMC532.

Parasuraman, A., and Grewal, D. (2000). The impact of technology on the quality-value-loyalty chain: a research agenda. Journal of the Academy of Marketing Science, 28(1), 168-174.

Ranganathan, C. and Ganapathy, S. (2002). Key dimensions of business-to-consumer web sites. Information \& Management, 39(6), 457-465.

Schaupp, L. C. and Bélanger, F. (2005). A Conjoint Analysis of Online Consumer Satisfaction1. Journal of Electronic Commerce Research, 6(2), 95.

Schlosser, A. E., White, T. B. and Lloyd, S. M. (2006). Converting web site visitors into buyers: how web site investment increases consumer trusting beliefs and online purchase intentions. Journal of Marketing, 70(2), 133-148.

Turban, E., King, D., Lee, J. and Viehland, D. (2002). Electronic commerce: A managerial perspective 2002. Prentice Hall: ISBN 0, 13(975285), 4.

Udo, G. J. (2001). Privacy and security concerns as major barriers for e-commerce: a survey study. Information Management \& Computer Security, 9(4), 165-174.

Wang, H. C., Pallister, J. G. and Foxall, G. R. (2006). Innovativeness and involvement as determinants of Website loyalty: II. Determinants of consumer loyalty in B2C e-commerce. Technovation, 26(12), 13661373. Wolfinbarger, M., \& Gilly, M. (2002). comQ: dimensionalizing, measuring, and predicting quality of the e-tail experience.

Yang, Z., and Peterson, R. T. (2004). Customer perceived value, satisfaction, and loyalty: The role of switching costs. Psychology \& Marketing, 21(10), 799-822.

Yoo, B., and Donthu, N. (2001). Developing a scale to measure the perceived quality of an Internet shopping site (SITEQUAL). Quarterly Journal of Electronic Commerce, 2(1), 31-45.

Zeithaml, V. A., Parasuraman, A., and Malhotra, A. (2000). Conceptual Framework for understanding eservice quality: Implications for future research and managerial practice. 